\title{
Use of native plants on federal lands: Policy and practice
}

\author{
REBECCA T. RICHARDS, JEANNE C. CHAMBERS, AND CHRISTOPHER ROSS
}

Authors are assistant professor, Department of Sociology, University of Montana, Missoula, Mont. 59812; research ecologist, USDA Forest Senice, Rocky Mountain Research Station, Reno, Nev 89512; and botanist, Bureau of Land Management, Nevada State Office, Minerals Division, Reno, Nev. 89520.

\begin{abstract}
Changing social values and advances in ecological knowledge determine native seed policy for revegetating range and forest lands. Natural resource managers are shifting from seeding introduced species for their widespread adaptability to reestablishing native species in order to maintain or restore the genetic and ecological integrity of native ecosystems. Addressing the problems of reestablishing native plants on a site-specific basis has been increasingly recognized as an integral part of ecosystem management of large landscapes. We review the formation and implementation of native seed policy for fire rehabilitation and mining reclamation by the major federal land management agencies in the United States, the Department of Interior's Bureau of Land Management (BLM) and the Department of Agriculture's Forest Service. We then examine native seed policy implementation on specific land revegetation projects over the past 10 years for 4 BLM districts in the state of Nevada. We conclude with an analysis of native seed policy in principle versus practice and suggest implications for future policy review and implementation.
\end{abstract}

Key Words: fire rehabilitation, mine reclamation, seed mixtures, policy development and implementation

Native seed policy for rangeland revegetation is based on changing social values and policy shifts as well as advances in ecological knowledge (Roundy et al. 1995, Johnson 1986, Hoberg 1997). Early revegetation efforts throughout the western U.S. focused either on abandoncd croplands or rangelands that had been severely degraded by livestock grazing. The primary objectives of these early efforts were watershed protection through soil stabilization and forage production. Much progress has been made in selecting adapted plant materials and developing revegetation technology since these early seedings in the $1930 \mathrm{~s}$. However, most revegetation projects since the 1950 s have emphasized native cultivars or introduced grass species like crested wheatgrass (Agropyron cristatum [L.] Gaertner) that have been selected or bred for adaptability to a wide range of site con-

Based on a paper presented at the Society for Range Management annual meeting in Rapid City, South Dakota, February 1997. The authors would like to thank all of the Forest Service and Bureau of Land Management employees who provided information and Durant McAurthur, Bruce Roundy, Lynn Huntsinger, Dave Pyke, and two anonymous reviewers who provided useful comments on an early draft.

Manuscript accepted 14 Dec. 1997. ditions (Pellant and Monsen 1993). These species are often easy to establish even after major soil disturbances. In addition, they often compete successfully with the spread of invasive weeds and nonnative annual grasses and provide additional livestock forage (Sherrets 1987, Pellant and Monsen 1993, Lesica and DeLuca 1996). While the importance of reestablishing native shrubs to improve wildlife habitat was recognized as early as the 1930 s and written into various policies in the 1960s, the low-cost availability and general adaptability of introduced grasses have maintained their popularity. Since 1984, supplemental, emergency fire rehabilitation funds have been available to revegetate burned rangelands to control erosion after wildfire. The preeminent species of choice have been introduced grasses like crested wheatgrass (Lesica and DeLuca 1996). Seeding introduced grasses has resulted in the widespread use of nonnative species on extensive areas of western range and forest lands and has discouraged the use of less easily established, more expensive, and less widely adapted species of native shrubs, grasses, and forbs (Pellant and Monsen 1993, Lesica and DeLuca 1996). Because of their competitive nature, these introduced species are effectively preempting establishment of native species on many of the sites on which they have been seeded (Chambers et al.1994, Walker 1997).

Since the 1980s, the widespread use of introduced species in revegetation projects has been debated both scientifically and politically. Many natural resource managers have gradually recognized that while introduced species may be useful in those situations where rapid establishment is desirable, native species are critical to maintaining and restoring the genetic and ecological integrity of western native ecosystems. With policy shifts in the last 30 years from commodity production to multiple uses, biodiversity, and ecosystem management, federal land managers are having to address the scale-associated problems of reestablishing native plants not only on site-specific projects but as part of the management of large landscapes. Although tremendous strides have been made in developing the technology for using native plants to restore disturbed ecosystems, the lack of methods for many important species continues to restrict their use. Also, the requirements for using locally adapted seed sources and specific seeding techniques are often viewed as barriers to using native plants by land managers.

Here, we review the formation and implementation of native seed policy for fire rehabilitation and mining reclamation projects of the major federal land management agencies in the United States, the Bureau of Land Management (BLM) and the Forest Service. We define native plants as naturally occurring species that evolved with or migrated naturally to a particular environ- 
ment or region and that were not introduced directly or indirectly according to historical record or scientific analysis. Our review of the use of native plants on federal lands is based on interviews with agency personnel and analysis of existing statutes, formal policies, and rules and regulations. As a case study, we also examine native seed policy implementation on specific land revegetation projects over the past 10 years for 4 BLM districts in the state of Nevada. We conclude with an analysis of native seed policy in principle versus practice and suggest implications for future policy review and implementation.

Introduced versus Native Species Use: Problem Definitions

In recent years, resource managers have increasingly encountered the question of when and where native plant material, primarily seed, should be used to revegetate, rehabilitate, restore, and/or reclaim ${ }^{1}$ natural ecosystems on public lands. Federal policy on the use of native plant material on public lands has been shaped by the emerging social and scientific definitions of how best to revegetate disturbed ecosystems. Definitions of the revegetation problem have often revolved around the preservation of threatened or endangered plants and animals and their critical habitats, the control of introduced weeds, and the maintenance or restoration of native ecosystems in the context of range and forest landscapes. These problem definitions continue to be debated, and the statutory and rule-making mechanisms of legitimizing native plant policy definitions have only recently emerged. The statutory authorizations providing the management framework for seeding federal lands with native plant material have only appeared in the last 30 years, and field level native plant policies and manuals have only materialized in the last 5 years.

The economic and ecological tradeoffs of native plant policy implementation have been even more controversial. Native plant policy has been implemented erratically on federal lands because of the shifting political power of different interest group constituencies supporting or opposing the use of native plant materials, the vaguely specified legislative statutes, the threat of legal challenges and statutory interpretation by the courts, and the discretionary ability of managers to interpret existing policy statutes and rules. At the field level, agencies are constrained in policy implementation by both limited budgets and finite expertise. While the general policy framework governing the use of native and nonnative plant species is still emerging for the resource manager, effectively implementing specific management plans at the field level requires his or her understanding of the ongoing debate defining the revegetation problem and the policy tradeoffs associated with it.

\section{The Policy Framework Governing Native Plant Use}

The governing acts for native plant use on federal lands originate from Congress and are administered through the President. The President may issue executive orders expanding or constrain-

\footnotetext{
In this paper, we are using these revegetation and related terms as follows: revegetate refers to the establishment of vegetation following land disturbance; rehabilitate refers to producing an alternative ecosystem that is consistent with existing land uses but that has a different structure and function from the original system, such as pastures and croplands; restore refers to the manipulation of natural processes of ecological succession to create self-organizing native ecosystems as they exist before land disturbance, and reclaim refers to creating ecosystems that are self-organizing and exhibit a high degree of similarity to the original or undisturbed ecosystem but may include introduced species that respond like the organisms they replace (National Academy of Sciences 1974).
}

ing Congressional Acts. Since the U.S. government is a federal system that relies on the relative autonomy of the nation and its separate states, Congress delegates its legislative authority to the federal and state agencies to interpret and enforce. The federal agencies make rules and regulations to follow Congress' policy intents and purposes within the scope of the Administrative Procedure Act of 1946. Specific decisions on when and where to use native plants are made at the field office level of the agencies by following manual rules and policy direction. Because challenges to federal or state legislative authority may be presented to the courts, field level revegetation decisions may be legally challenged, particularly on procedural grounds based on the statutes and rules. While court challenges have not been common in the past, increasing public interest in preserving natural landscapes while living with larger ecological disturbances is increasing the likelihood that revegetation plans will be legally contested in the future. Thus, an effective resource manager can achieve revegetation policy goals only by recognizing substantive policy direction and developing procedurally sound land management plans.

\section{Native Plant Policy for the Forest Service and BLM}

While many agencies may be involved in revegetation activities, the primary responsibility for managing and revegetating federal range and forest land, excluding national parks, is generally that of the 2 major land management agencies, the Forest Service and the BLM. Since the beginning of the National Forest system with the Organic Act of 1897, the Forest Service has been charged with conserving and protecting the timber and watersheds of federal forests. The BLM public lands originated from those lands remaining in the General Land Office, which included the federal mineral leasing program, and the early Grazing Service (Clawson 1983). In historical terms, the Forest Service has been the nation's fire manager and the BLM has been the federal minerals and grazing supervisor (Loomis 1993). In reality, both agencies have fire, mining, and grazing related duties. To provide for wildlife species, the two agencies often share those resource management duties with the U.S. Fish and Wildlife Service (USFWS) and with state fish and game departments. These duties are often complex and interlocking and are central to understanding native plant policy and implementation at the field level.

In the last 3 decades, various environmental acts have provided the basic policy framework dictating the use of native plant materials in revegetating range and forest ecosystems on federal lands. The first major environmental laws affecting seeding activity on Forest Service and BLM lands were the Multiple Use Sustained Yield Act (MUSY) of 1960 and the Classification and Multiple Use Act (CMUA) of 1964 (which expired in 1970). MUSY and CMUA reflected Congress' recognition of increasing public concern for environmental changes on Forest Service and BLM lands and mandated the agencies to manage not only for consumptive resource uses but for wildlife habitat and recreational purposes as well (Clawson 1983, Loomis 1993). These 2 statutes provided the first policy shift from planting better livestock forage, often in the form of crested wheatgrass, to revegetating critical wildlife habitat areas with native shrubs, forbs, and grasses. Special management provisions for multiple use in designated wilderness areas followed in the Wilderness Act of 1964, for the Forest Service and later in 1976 for the BLM, and generally strengthened the policy direction for revegetating federal lands with native species. 
In 1969, Congress acknowledged the growing interest of the American public to participate directly in addressing environmental issues by passing the National Environmental Policy Act (NEPA). NEPA not only directed all federal agencies to consider the environmental impacts of ecosystern disturbance but to initiate environmental assessments and public participation in mitigating disturbance (Buck 1991). The degree to which NEPA procedures are to be followed is authorized by the Council on Environmental Quality (CEQ) whose members are appointed by the President. NEPA not only provides statutory protection of natural ecosystems on federal lands but also offers the public the opportunity to consider the environmental implications of revegetating federal landscapes with introduced versus native plants.

The framework for planning how to manage for ecosystem disturbance on federal lands followed with the Forest and Rangeland Renewable Resources Planning Act (RPA) of 1974. The 2 main purposes of the RPA were to require federal agencies to conduct a national assessment of the demand and supply of natural resources on all lands in federal ownership and to develop a specific program for management direction of national forests in particular (Clawson 1983, Loomis 1993). This RPA planning mandate was followed in 1976 by the National Forest Management Act (NFMA) that required the Forest Service to submit individual national forest plans every 5 years. In the same year, the Federal Land Policy and Management Act (FL.PMA) replaced the expired CUSA and specified how the BLM should respond to national RPA land assessment direction (Davis 1997a). Through FLMPA, the BLM was authorized to plan and manage for amenity and biodiversity values, make BLM lands eligible for wilderness designation, and control the extraction of locatable minerals on federal lands (Loomis 1993).

Finally, the passage of the Endangered Species Act of 1973, which was amended in 1978, recognized the public's interest in rare plants and animals and shifted responsibility for those species from state to federal control. In addition, the Endangered Species Act required all the federal agencies to conserve rare plants and animals at population levels that would remove them from danger of extinction and to restore their habitats. As the primary caretaker of endangered wildlife species, the USFWS is the lead agency in administering the Endangered Species Act . Thus, revegetation efforts involving threatened or endangered plant or animal species on Forest Service or BLM lands are subject to USFWS oversight (Loomis 1993).

\section{Forest Service and BLM Policies for Fire Rehabilitation and Mine Reclamation}

In practice, native plant policy can best be understood in terms of not only the federal agency that administers it, but the purposes for which the policy was designed to serve. These purposes can range from riparian improvement to roadside stabilization. Here we focus on the 2 largest revegetation efforts, wildfire rehabilitation and mining reclamation projects. Fire rehabilitation projects are primarily aimed at immediate watershed protection with secondary goals of enhancing wildlife habitat, increasing forage production, and preventing the spread of invasive plant species. Because fire rehabilitation projects are generally designed to temporarily or permanently reestablish only a part of the general plant community, often the grass component, the long-term effects on ecosystem dynamics resulting from these watershed protection efforts are seldom considered. In contrast, mining reclamation projects aim to stabilize a disturbed site and establish a productive vegetative community based on the applicable land use plan and designated post-mining land uses. Usually, this means a native ecosystem capable of natural successional processes.

Although both fire rehabilitation and mining reclamation projects have been viewed as relatively small-scale, site-specific efforts, fire rehabilitation has become increasingly a landscape level problem because of the large number of acres burned in recent years (Pellant and Monsen 1993). For example, in Nevada alone, there were 5 years from 1951 to 1996 when over 40,468 ha of BLM land burned. Four of these years occurred between 1984 and 1996, and the record year was 1996 when 314,488 ha burned (BLM fire statistics 1997, unpublished).

\section{Native Seed Policy in Fire Rehabilitation Projects}

Although the BLM and the Forest Service address the use of prescribed fire in resource management plans through FLMPA and NFMA, respectively, most fire rehabilitation projects result from wildfires and are uncertain events in the land management planning process. Because wildfires cause unpredictable environmental impacts, they are treated, although somewhat differently, as NEPA emergencies by both agencies. Since wildfires arguably cause the greatest ecosystem change on a large landscape scale for most western public lands, the supplemental funding restrictions that limit native plant revegetation following wildfire have impacts far beyond their narrow intent only to protect watersheds from erosion.

While the National Forest Management Act, as reinforced by Title 36 of the Federal Code, directs the Forest Service to conserve biological diversity including "endemics and desirable naturalized plant and animal species," emergency fire funding restrictions dictate reseeding for watershed protection and "protection of life and property" and do not allow for wildlife habitat improvement or other ecosystem functions. Where emergency watershed conditions follow a wildfire and threaten life, property, and other downstream values, a multidisciplinary team of the Forest Service develops Burned Area Emergency Rehabilitation (BAER) plans within 3 days after the fire has been declared controlled. The team develops a series of alternative actions, one of which is recommended by the team for the BAER lead forest supervisor's approval. Funding for the BAER evaluation and implementation is provided by emergency fire suppression funds. In contrast, long-tcrm Forest Service fire recovery projects are planned and executed by the national forest resource staff and funded from annual operating budgets. In both short and longterm fire recovery efforts, Forest Service manual policies, particularly those formally developed in the Pacific Northwest, Pacific Southwest, and Northern Regions, encourage the use of native seed where it is feasible, practical, and affordable.

Historically, the Forest Service has not sought NEPA oversight from the CEQ since significant environmental impacts resulting from wildfire rehabilitation actions have been viewed by the agency as emergency actions. However, because of the intensive treatments (e.g., contour trenching) that were recommended for watershed protection following the Boise National Forest fires of 1996, the Forest Service is currently classifying BAER treatments as those that will be either exempt or nonexempt from CEQ approval in the future. These treatment classifications will then be considered in future national forest plan revisions under NFMA.

In contrast to the Forest Service, the BLM develops an 
Emergency Management Rehabilitation (EMR) plan for each major wildfire as a NEPA environmental assessment on a particular resource area. Each EMR plan includes various fire rehabilitation treatment actions. An interdisciplinary BLM team recommends a particular action alternative to the area manager who in turn issues a decision memo prescribing the chosen alternative. For policy guidance on EMR decision memos, BLM area managers rely on FLMPA and an Executive Order from President Jimmy Carter in 1977 that mandates the Secretary of the Interior, in consultation with the Secretary of Agriculture, to restrict introduced species and encourage the use of native species. Because of FLMPA, the BLM is directed to reseed burned areas with species that will produce wildlife habitat as well as control soil erosion. These species should include native plants, particularly shrubs. The Presidential order primarily guides the BLM national rules set forth in Manual 1745 (1992) that require the site-specific evaluation of the use of nonnative plants in all activity plans, including both normal and emergency fire rehabilitation projects, and site-specific environmental assessments unless waived by the state BLM director. This evaluation is also guided by BLM Manual 1742 (1985) that describes fire rehabilitation procedures. The California state BLM office has recently reinforced national BLM directives with a 1996 state policy that not only requires the evaluation of the use of nonnative species but "strongly promotes"' the use of native plants and the "preservation of local adaptation" in the native gene pool. Similarly, state BLM policy in Idaho has encouraged the use of native plants in fire rehabilitation projects since 1995.

\section{Native Seed Policy in Mining Reclamation Projects}

Although mining reclamation projects do not typically involve as many acres as fire rehabilitation efforts, current mining exploration and extraction methods result in much larger reclamation projects than in the past. In addition, reclamation projects involve more complex agency jurisdiction than fire rehabilitation efforts since both state and federal laws may apply. Prior to 1873, all valuable minerals could be located under the Mining Law of 1872. In 1873, a separate surface mining system was established by Congress for coal deposits and in 1920, the Mineral Leasing Act created a leasing system for fossil fuels (oil, gas, and oil shale) and fertilizer minerals (potassium, sodium, and phosphate) under federal supervision (MacDonnell 1993). As a result, regulatory statutes for mining reclamation projects are based on the mining designation of locatable, leasable, or surface mineral deposits and the amount of acreage involved (R-4 Reclamation Field Guide, n. d.).

Under the 1872 Mining Law, locatable (hardrock) mineral deposits on open federal lands are available for exploration and purchase. Monitoring of locatable mineral mining operations on federal lands has generally been authorized through the multiple use statutes, MUSY and NFMA for the Forest Service and FLMPA for the BLM.

The Mineral Leasing Act of 1920 authorized the BLM to issue leases for leasable minerals (generally, phosphate, sodium, oil, and natural gas) on all public lands, including national forests. Lease plans are approved through FLMPA, which requires the leasee to file environmental assessments with the BLM. Regulations governing locatable and leasable minerals are specified in Title 43, Code of Federal Regulations, and are administered by the BLM.
Mining rights for surface mineral deposits on national forests have been protected under the Organic Administration Act of 1897, which has also given the Forest Service the authority to administer surface as well as locatable mineral operations on national forests. This authority is reinforced by the Multiple-Use Mining Act of 1955 that authorizes Forest Service and BLM management of surface resources on mining claims without interfering with the claimant's rights. In addition, FLMPA and Title 43 reinforce BLM authorization to monitor surface mining operations on BLM lands. In general, reclamation is required once mining operations cease and include revegetation and protection of surface water resources (MacDonnell 1993).

Surface coal mine as well as abandoned mine operations on national forests or BLM lands are regulated through the Department of Interior's Office of Surface Mining Reclamation and Enforcement (OSM) and the individual states, whose regulations must meet or exceed the federal laws, but with Forest Service or BLM concurrent approval. Monitoring authority for reclamation projects following surface coal and abandoned mine operations on national forest or BLM land falls to the respective land management agency and the state (Davis 1997b). In this case, both the Forest Service and the BLM are directed by the Surface Mining Control and Reclamation Act (SMCRA) of 1977 to require that a "diverse, effective, and permanent vegetative cover of the same seasonal variety native to the area of land to be affected and capable of self-regeneration and plant succession" be established.

Under the various statutes and titles, the reclamation plan is developed as part of the mining operation plan by the operator with input from the surface administrator and consistent with NEPA environmental assessment requirements. Depending on the nature of the mineral resource and the location of the mine, the Forest Service, the BLM, or both may have responsibility for review, recommendation, approval, and monitoring of these plans. The plan must describe in delail the anticipated mitigation of the operation's impacts on the site and how the land will be reclaimed to a productive state consistent with the long-term management objectives of the agency (R-4 Reclamation Field Guide, n. d.).

\section{Native Plant Practice: A Case Study}

Although general policy direction for both the Forest Service and the BLM clearly emphasizes the use of native plants in fire rehabilitation and mining reclamation projects, specific policy objectives and project scale differ by agency and revegetation purpose. In contrast to mining reclamation efforts, fire rehabilitation projects generally aim to provide short-term watershed protection rather than long-term ecosystem biodiversity. While fire rehabilitation projects typically involve thousands of burned acres, mining reclamation efforts usually affect hundreds of acres. To determine the degree to which different policy objectives and project scales affect patterns of reclamation in actual native plant policy implementation, we examined the types and numbers of species included in seed mixtures used or recommended by the BLM in the state of Nevada on mine reclamation vs. fire rehabilitation projects.

Seed mixture data were collected from 4 BLM districts (Battle Mountain, Elko, Ely, and Winnemucca) for 26 different mine reclamation projects and 50 different fire rehabilitation treatments. All available data were obtained. Information from the 
mine reclamation plans included seed mixtures that had been used on 32 different mined sites with 5 to 10 sites for each of the four districts. Information from the fire rehabilitation treatments included 5 to 28 sites for each of the four districts. The seed mixtures for the mined sites werc used during the period from 1988 through 1996 while those for the fire sites were used from 1984 through 1996. The plant community types included for the mine reclamation and fire rehabilitation sites ranged from mountain brush to salt desert shrub, but different naming conventions and the lack of information on plant community types for most sites made it impossible to provide a synthesis of this information. The nomenclature used for individual species follows Cronquist et al. 1977, Welch et al. 1993, and Hickman 1993. Nomenclature of the Triticeae follows Barkworth and Dewey 1985 and M. E. Barkworth, personal communication.

Two-way analysis of variance was conducted to examine the differences between seed mixtures used on mined sites versus fire sites and among districts. Mean comparisons were conducted using Fisher's Protected Least Significant Differences (LSDs). The variables examined included the overall total number of species, the total number of grass, forb, and shrub species, and the total number of native and introduced species. To evaluate which species were most commonly used in the seed mixtures, species frequencies were calculated for all mined and fire sites.

\section{Case Study Results}

More species of grasses, forbs, and shrubs were seeded onto mined sites than onto fire sites (Fig. 1). Although an average of 12 species were seeded onto mined sites, only 4 species were
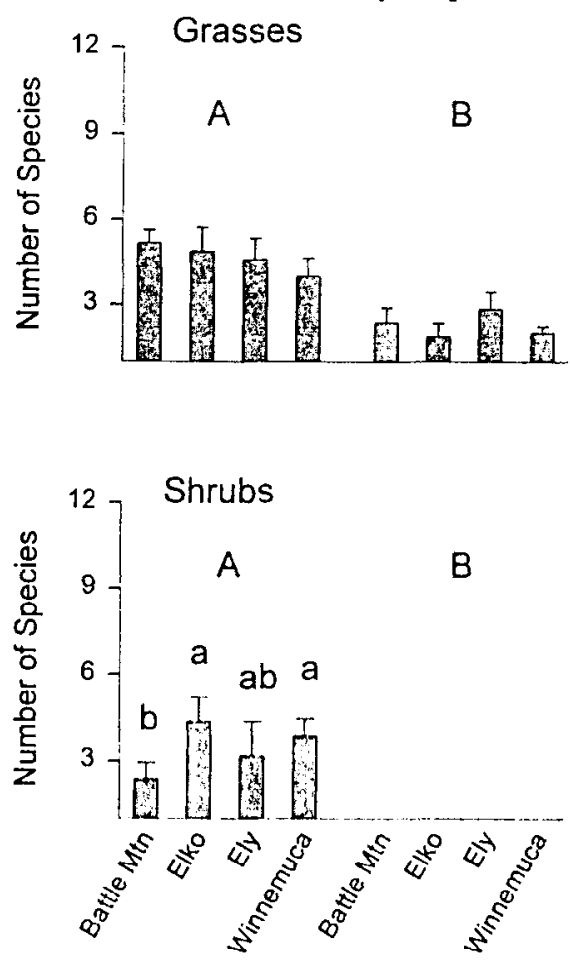

Mine

Fire seeded on fire sites. The maximum number of species seeded onto mined sites was 21 and on fire sites was 8 , and the minimum number of species were 5 and 1 , respectively. Lower numbers of forb and shrub species than grass species were seeded onto both mined and fire sites $(\mathrm{p}<0.05$ ). Few differences existed among BLM districts in the numbers of species seeded for grasses, forbs, or shrubs on either mined or fire sites. Only the numbers of shrubs seeded on mined sites differed among districts, with the Battle Mountain District seeding fewer species of shrubs than any of the other districts.

The majority of species (10 of 12) seeded onto mined sites were natives (Fig. 2). In contrast, slightly less than half ( 1.7 out of 4) of the few species seeded onto fire sites were natives. Although the numbers of introduced species seeded onto fire sites were similar, the proportion of introduced species seeded on fire sites was much higher than on mined sites because of the differences in the total number of seeded species.

While a total of 71 species were seeded onto the mined sites, only 32 species were seeded onto the fire sites (Table 1). Almost all of the species that were seeded on fire sites were also seeded on mined sites. The species most frequently seeded on fire sites tended to be introduced, commercially available, and relatively inexpensive species such as crested wheatgrass, Siberian wheatgrass (Agropyron fragile [Roth] Candargy), alfalfa (Medicago sativa L.), and small burnet (Sanguisorba minor Scop.). Most of the species used on fire sites were broadly adapted. In contrast, the species most frequently used on mined sites were native species that are reasonably available and moderately priced, including western wheatgrass (Pascopyron smithii [Rydb.] Löve),
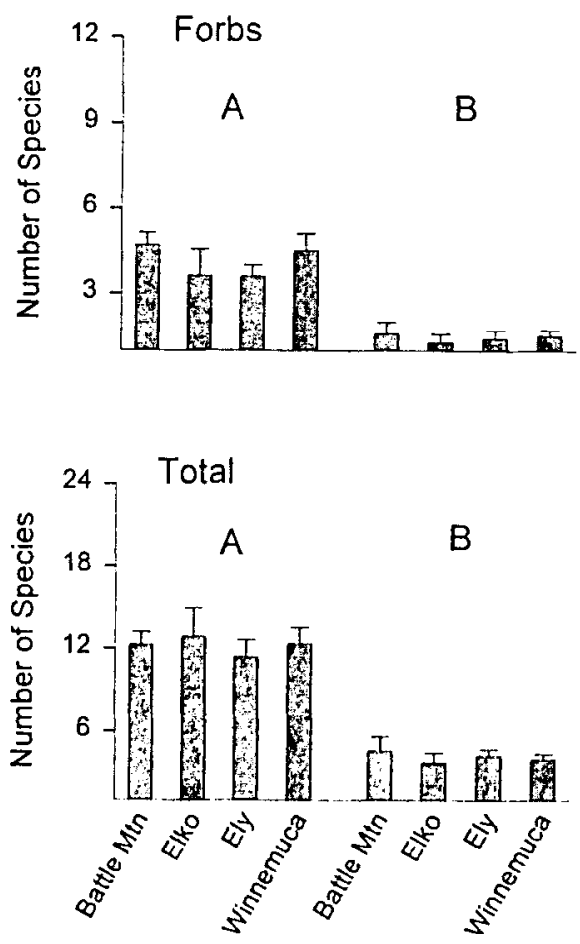

Mine

Fig. 1. The total number of species and the number of grasses, forbs, and shrubs used in seed mixes on mine vs. fire sites on four BLM districts in Nevada. Values are mean \pm standard error. Unlike upper case letters indicate significant differences $(P \leq 0.05)$ between mine and fire sites. Unlike lower case letters indicate significant differences ( $\leq 0.05)$ among BLM districts where present. 


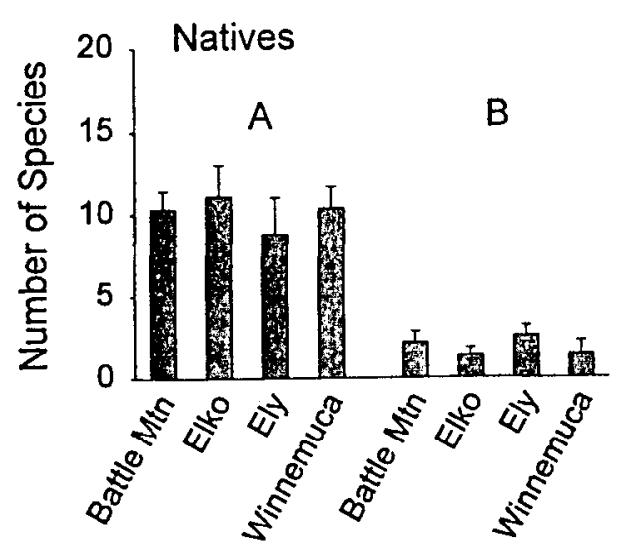

Mine

Fire

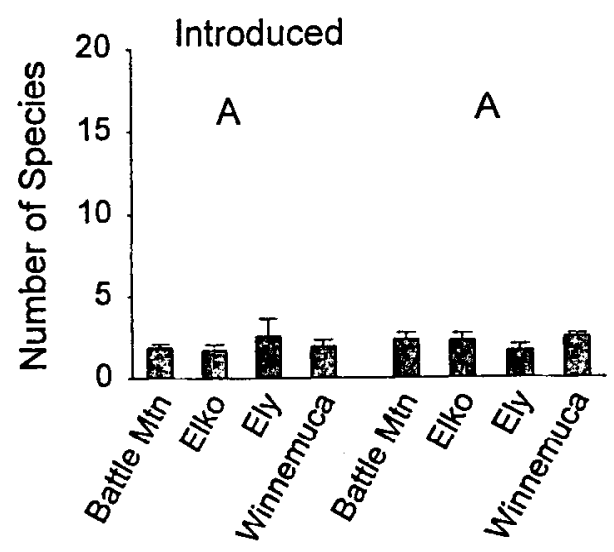

Mine

Fire

Fig. 2. The number of native and introduced species used in seed mixes on mine vs. fire sites on four BLM districts in Nevada. Values are mean \pm standard error. Unlike upper case letters indicate significant differences $(P \leq 0.05)$ between mine and fire sites.

bluebunch wheatgrass (Pseudoroegneria spicata [Pursh] Löve), Great Basin wildrye (Leymus cinereus [Scribn. \& Merr.] A. Löve), Indian rice grass (Achnatherum hymenoides [R. \& S.] Barkworth), blue flax (Linum lewisii Pursh), fourwing saltbush (Atriplex canescens [Pursh] Nutt.), and antelope bitterbrush (Purshia tridentata [Pursh] DC.). Many of the species seeded on the mined sites were adapted to specific precipitation regimes or site conditions such as Idaho fescue (Festuca idahoensis Elmer), sand dropseed (Sporobolus cryptandrus [Torr.] Gray), desert globemallow (Sphaeralcea ambigua Gray), black sagebrush (Artemisia nova A. Nels.), and winterfat (Ceratoides lanata [Pursh] J.T. Howell).

Because of limited information on seeding rates, our data set did not include the kilograms or numbers of seeds per hectare used for the individual species in the various seed mixtures. However, it is likely that because of the higher seed cost of native species and the widespread use of introduced species for watershed protection that natives were seeded at much lower rates than the introduced grasses and forbs.

This case study provides information on how different policy objectives and constraints may affect the degree to which native seed is actually used in different rehabilitation/reclamation efforts depending on the purpose of the project. Clearly, grasses are an important component of both types of reclamation efforts. The relative lower frequency and number of shrubs and forbs on both mined and fire sites may reflect the perceived importance of watershed protection goals. Many grass species rapidly establish on disturbed sites providing a high ground cover and stabilizing the soil surface. Biodiversity policy goals may be secondary to those of watershed protection in actual practice. The short-term policy objective of minimizing soil erosion, even at the expense of maintaining wildlife habitat, is reflected in the fire rehabilitation projects that we examined. These projects had significantly lower numbers and fewer species of native plants than mine reclamation sites in the same districts. While it can be argued that native species regeneration following fire should result in higher biodiversity, this doesn't explain the abundance of introduced species in the seeding mixes. Although the native species on the mined sites were specially adapted to the conditions that characteristize individual sites, the introduced species on the fire sites had broad ecological amplitudes. Fire rehabilitation projects, arguably the largest reclamation efforts to restore native ecosystems, do not yet reflect recent field level policy shifts to native plant use.

\section{Conclusions}

Many observers have noted the widespread changes in western U.S. ecosystems as a result of weed and nonnative annual grass invasions, more frequent and extensive wildfires, and the continued use of introduced grasses and forbs to reclaim degraded rangelands following disturbance (Pellant and Monsen 1993; Lesica and Deluca 1996). Although a policy framework authorizing the federal land management agencies to use native species has emerged in recent years, numerous problem definitions and practical constraints limit the degree to which the BLM and the Forest Service can implement native plant policy objectives. These include multiple land management objectives such as watershed protection and ecosystem biodiversity that may not be possible to achieve simultaneously. In terms of fire rehabilitation, these also include funding restrictions that limit the agency's capability to purchase, store and successfully establish native seed. This lack of flexibility is exacerbated by the limited supply, and frequently high cost, of native seed when demand, particularly following large wildfires, exceeds supply. In addition, many agency personnel note that the agency bears the costs when responding to wildfire with supplemental, publicly funded, emergency treatments. In contrast, the costs are transferred by the agency to the corporation in response to mining reclamation needs with approved, privately funded, long-term actions.

The implications of these findings suggest that overriding short-term policy objectives, supplemental funding restrictions, and free-market supply and demand economic cycles may be critical factors inhibiting native plant policy implementation on western rangelands. Agency changes are needed to establish more consistency between native plant policy and practice. Policy directives need to be developed that are consistent within both the BLM and Forest Service and that are similar and clearly stated for all administrative levels. Current Forest Service national 
Table 1. The native and introduced (N/I) species seeded on BLM mine reclamation $(n=32)$ and fire rehabilitation $(n=50)$ sites in Nevada and the percentage of sites on which each species was seeded.

\begin{tabular}{|c|c|c|c|}
\hline Species & $\mathbf{N} / \mathbf{I}$ & Mine & Fire \\
\hline & & $(\%)$ & $(\%)$ \\
\hline $\begin{array}{l}\text { Grasses } \\
\text { Achnatherum hymenoides - Indian ricegrass } \\
\text { Achnatherum thurberianum - Thurber's needlegrass } \\
\text { Agropyron cristanum - crested wheatgrass } \\
\text { Agropyron cristatum x desertorum - Hycrest crested wheatgrass } \\
\text { Agropyron desertorum - desert crested wheatgrass } \\
\text { Agropyron fragile - Siberian wheatgrass } \\
\text { Agropyron spp. - wheatgrass } \\
\text { Bouteloua curtipendula - sideoats gramma } \\
\text { Bromus inermis - smooth brnme } \\
\text { Elymus elymoides - squirreltail } \\
\text { Elymus lanceolatus* - streambank wheatgrass } \\
\text { Elymus lanceolatus - thickspike wheatgrass } \\
\text { Elymus trachycaulus - slender wheatgrass } \\
\text { Festuca idahoensis - Idaho fescue } \\
\text { Festuca ovina - sheep fescue } \\
\text { Hesperostipa comata - needle and thread grass } \\
\text { Pleuraphis jamesii- galleta } \\
\text { Leymus cinereus - Great Basin wildrye } \\
\text { Secale cereale - annual rye } \\
\text { Pascopyrum smithii - western wheatgrass } \\
\text { Poa canbyi - Canby bluegrass } \\
\text { Poa secunda - Sandberg bluegrass } \\
\text { Poa spp. - bluegrass } \\
\text { Psathyrostachys juncea - Russian wildrye } \\
\text { Pseudoroegneria spicata - bluebunch wheatgrass } \\
\text { Sporobolus cryptandrus - sand dropseed } \\
\text { Sporobolus giganteus - giant dropseed } \\
\text { Thinopyrum intermedium* - pubescent wheatgrass } \\
\text { Thinopyrum intermedium* - intermediate wheatgrass } \\
\text { Thinopyrum ponticum - tall wheatgrass }\end{array}$ & $\begin{array}{c}\mathbf{N} \\
\mathbf{N} \\
\mathbf{I} \\
\mathbf{I} \\
\mathbf{I} \\
\mathbf{I} \\
\mathbf{N} \\
\mathbf{N} \\
\mathbf{I} \\
\mathbf{N} \\
\mathbf{N} \\
\mathbf{N} \\
\mathbf{N} \\
\mathbf{N} \\
\mathbf{N} \\
\mathbf{N} \\
\mathbf{N} \\
\mathbf{N} \\
\mathbf{I} \\
\mathbf{N} \\
\mathbf{N} \\
\mathbf{N} \\
\mathbf{N} \\
\mathbf{I} \\
\mathbf{N} \\
\mathbf{N} \\
\mathbf{N} \\
\mathbf{I} \\
\mathbf{I} \\
\mathbf{I}\end{array}$ & $\begin{array}{c}81 \\
0 \\
22 \\
0 \\
6 \\
3 \\
12 \\
3 \\
0 \\
22 \\
16 \\
19 \\
6 \\
9 \\
6 \\
22 \\
3 \\
62 \\
3 \\
41 \\
6 \\
41 \\
3 \\
3 \\
53 \\
3 \\
3 \\
9 \\
6 \\
3\end{array}$ & $\begin{array}{c}6 \\
2 \\
38 \\
6 \\
20 \\
36 \\
6 \\
0 \\
6 \\
0 \\
6 \\
8 \\
2 \\
0 \\
0 \\
2 \\
0 \\
24 \\
0 \\
6 \\
2 \\
0 \\
0 \\
6 \\
12 \\
0 \\
0 \\
14 \\
10 \\
6\end{array}$ \\
\hline $\begin{array}{l}\text { Forbs } \\
\text { Achillea millefoilum lanulosa - western yarrow } \\
\text { Aster scopulorum - crag aster } \\
\text { Astragalus cicer - Cicer milkvetch } \\
\text { Balsamorhiza sagittata - balsam-root } \\
\text { Castilleja chromosa - desert paintbrush } \\
\text { Eriogonum fasciculatum - flat top buckwheat } \\
\text { Eschscholzia californica - California poppy } \\
\text { Eriastrum diffusum - desert gilia } \\
\text { Hedysarum boreale - northern sweetvetch } \\
\text { Kochia prostrata - prostrate kochia } \\
\text { Kochia scoparia - summer-cyprus } \\
\text { Linum lewisii - blue flax } \\
\text { Lupinus arbustus - spur lupinc } \\
\text { Lupinus caudatus - tailcup lupine } \\
\text { Medicago sativa - alfalfa } \\
\text { Melilorus officinalis - yellow sweetclover } \\
\text { Oenothera caespitosa - fragrant evening primrose } \\
\text { Onobrychis viciifolia - sainfoin } \\
\text { Penstemon palmeri - Palmer penstemon } \\
\text { Sanguisorba minor - garden bumet } \\
\text { Sphaeralcea ambigua - apricot globemallow } \\
\text { Sphaeralcea grossulariifolia - gooseberry-leaf globemallow } \\
\text { Wyethia amplexicaulis - mules ears }\end{array}$ & $\begin{array}{c}\mathbf{N} \\
\mathbf{N} \\
\mathbf{I} \\
\mathbf{N} \\
\mathbf{N} \\
\mathbf{N} \\
\mathbf{N} \\
\mathbf{N} \\
\mathbf{N} \\
\mathbf{I} \\
\mathbf{I} \\
\mathbf{N} \\
\mathbf{N} \\
\mathbf{N} \\
\mathbf{I} \\
\mathbf{I} \\
\mathbf{N} \\
\mathbf{I} \\
\mathbf{N} \\
\mathbf{I} \\
\mathbf{N} \\
\mathbf{N} \\
\mathbf{N}\end{array}$ & $\begin{array}{c}19 \\
0 \\
25 \\
28 \\
3 \\
3 \\
3 \\
3 \\
22 \\
31 \\
3 \\
50 \\
19 \\
3 \\
38 \\
19 \\
3 \\
16 \\
38 \\
50 \\
19 \\
12 \\
16\end{array}$ & $\begin{array}{c}2 \\
2 \\
0 \\
0 \\
0 \\
0 \\
0 \\
0 \\
0 \\
16 \\
0 \\
16 \\
0 \\
0 \\
32 \\
12 \\
0 \\
16 \\
0 \\
50 \\
0 \\
0 \\
0\end{array}$ \\
\hline $\begin{array}{l}\text { Shrubs } \\
\text { Amelanchier utahensis - Utah serviceberry } \\
\text { Artemisia nova - black sagebrush } \\
\text { Artemisia tridentata tridentata - basin big sagebrush } \\
\text { Artemisia tridentata wyomingensis - Wyoming big sagebrush } \\
\text { Atriplex confertifolia - shadscale } \\
\text { Ceratoides lanata - winterfat } \\
\text { Cercocarpus ledifolius - curl-leaf mountain mahogany } \\
\text { Chrysothamnus nauseosus - rubber rabbitbrush } \\
\text { Chrysothamnus spp. - rabbitbrush } \\
\text { Chrysothamnus viscidiflorus - yellow rabbitbrush } \\
\text { Ephedra nevadensis - Nevada ephedra } \\
\text { Grayia spinosa - spiny hopsage } \\
\text { Purshia mexicana - cliffrose } \\
\text { Purshia tridentata - bitterbrush } \\
\text { Ribes velutinum - plateau gooseberry } \\
\text { Rosa woodsii - Wood's rose } \\
\text { Shepherdia argentea - buffaloherry } \\
\text { Symphoricarpos albus - common snowberry } \\
\text { Symphoricarpos oreophilus - mountain snowberry }\end{array}$ & $\begin{array}{l}\mathbf{N} \\
\mathbf{N} \\
\mathbf{N} \\
\mathbf{N} \\
\mathbf{N} \\
\mathbf{N} \\
\mathbf{N} \\
\mathbf{N} \\
\mathbf{N} \\
\mathbf{N} \\
\mathbf{N} \\
\mathbf{N} \\
\mathbf{N} \\
\mathbf{N} \\
\mathbf{N} \\
\mathbf{N} \\
\mathbf{N} \\
\mathbf{N} \\
\mathbf{N}\end{array}$ & $\begin{array}{c}6 \\
12 \\
9 \\
22 \\
28 \\
47 \\
12 \\
22 \\
3 \\
3 \\
16 \\
9 \\
12 \\
47 \\
3 \\
3 \\
3 \\
3 \\
3\end{array}$ & $\begin{array}{l}0 \\
0 \\
0 \\
8 \\
2 \\
0 \\
0 \\
0 \\
0 \\
0 \\
0 \\
2 \\
0 \\
6 \\
0 \\
0 \\
0 \\
0 \\
0\end{array}$ \\
\hline
\end{tabular}

*Current synonymy combines these species. They are listed separately in BLM seed mixes. 
office efforts to develop a national native plant policy for all regions and current BLM national office efforts to review the fire rehabilitation manual are steps toward this action.

Funds need to be provided specifically to encourage the production, stockpiling and use of native seeds. This is particularly important for fire rehabilitation projects where the costs of reclamation are borne by the taxpayers rather than private corporations. Funded native seed production and storage would not only avoid the unpredictability of emergency funding constraints, but contribute to stabilizing the supply and demand economic cycle that often makes it difficult to use native seeds. The native seed production and storage models in use or under development by various agencies such as the National Interagency Fire Center, the Utah Division of Wildlife Resources, and the Manti-LaSal National Forest are good working examples of the benefits of this recommendation at several administrative levels.

Another avenue available to both the Forest Service and BLM for increasing native seed availability is to encourage harvesting native seeds on federal lands by developing consistent seed harvesting permit systems (Richards 1995). These systems would allow areas with the capacity for seed production of specific species to be identified. Once these areas had been identified, they could be managed specifically for native seed production.

Finally, increased emphasis needs to be placed on developing the ecological and technical knowledge necessary for increasing native seed availability at reasonably local levels. Although maintaining the genetic integrity of native species is of increasing concern, the scale at which the genetic integrity of native ecosystems is compromised by using distant seed sources has yet to be examined and needs to be determined (Rice 1995). At the same time, methods that are developed for increasing native seed availability need to be economically viable in terms of market forces. Research and development efforts need to be conducted in cooperation among the native seed industry, the universities, and the federal and state agencies. These efforts need to be politically supported by national policy direction and by separate funding. Collaboration by the USFS, Rocky Mountain Research Station's Shrub Sciences Laboratory and native seed producers in the region to develop methods for harvesting a wide variety of native species is but one example of the ways in which constraints on policy implementation can be overcome in practice.

\section{Literature Cited}

Barkworth, M. E. and D. R. Dewey. 1985. Gemomically based genera in the perennial Triticeae of North America: identification and membership. Amer. J. Bot. 72:767-776.

Buck, Susan J. 1991. Understanding environmental administration and law. Island Press, Washington, D.C.

Chambers, J. C., R. W. Brown, and B. D. Williams. 1994. An evaluation of reclamation successon on Idaho's phosphate mines. Rest. Ecol. 2:4-16.

Clawson, Marion. 1983. The federal lands revisited. Resources for the Future, Washington, D.C.

Cronquist, A., A. H. Holmgren, N. H. Holmgren, J. L. Reveal, and P. K. Holmgren. 1977. Intermountain flora: Vascular plants of the Intermountain West, U.S.A. Vol. 6. The Monocotyledons. The New York Botanic Garden, New York, N.Y.

Davis, Charles. 1997a. Politics and public rangeland policy, pp. 74-94. In: Charles Davis (ed.), Western public lands and environmental politics. Westview Press, Boulder, Colo.
Davis, David H. 1997b. Energy on federal lands, pp. 122-149. In: Charles Davis (ed.), Western public lands and environmental politics. Westview Press, Boulder, Colo.

Hickman, J. C. (ed.). 1993. The Jepson manual: higher plants of California. Univ. of California Press, Berkeley, Calif.

Hoberg, George. 1997. From localism to legalism: The transformation of federal forest policy, pp. 47-73. In: Charles Davis (ed.), Western public lands and environmental politics. Westview Press, Boulder, Colo.

Johnson, Kendall L. (ed.). 1986. Crested wheatgrass: Its values, problems, and myths. Utah State Univ., Logan, Ut.

Lesica, Peter and Thomas H. DeLuca. 1996. Long-term harmful effects of crested wheatgrass on Great Plains grassland ecosystems. J. Soil and Water Conserv. September-October: 408-409.

Loomis, John B. 1993. Integrated public lands management: Principles and applications to national forests, parks, wildlife refuges, and BLM lands. Columbia Univ., Press, New York, N.Y.

MacDonnell, Lawrence J. 1993. Mineral law in the United States: A study in legal change, pp. 66-93. In: Lawrence J. MacDonnell and Sarah F. Bates (eds.), Natural resources policy and law: Trends and directions. Island Press, Washington, D.C.

National Academy of Sciences.1974. Rehabilitation of western coal lands. J.B. Lippencott, Boston, Mass.

Pellant, Mike and Steve Monsen. 1993. Rehabilitation on public rangelands in Idaho, USA: A change in emphasis from grass monocultures, pp. 778-779. In: Proceedings of the XVII International Grassland Congress. New Zealand Grassl. Assoc., Rockhampton, Queensland, Australia.

R-4 Reclamation Field Guide. n.d. USDA For. Serv. Region 4, Minerals Manage., Ogden, Ut.

Rice, K. J. 1995. Managing exotic versus native flora and fauna. pp. 27 29. In: W. Daniel Edge and Sally L. Olsen-Edge (eds.), Proceedings from the 1994 Sustaining Rangeland Ecosystems Symposium. Oregon State Univ. SR953, Corvallis, Ore.

Roundy, B. A., E.D. McArthur, J.S. Haley, and D.K. Mann. (eds.). 1995. Proceedings of the wildland shrub and arid land restoration symposium. USDA Forest Serv. Gen. Tech. Rep. INT-GTR-315. Ogden, Ut.

Sherrets, Harold D. 1987. Vegetation suitable for rehabilitating burned areas in southern Idaho. Idaho BLM Tech. Bull. 87-1. Boise, Ida.

Walker, Scott. 1997. Species compatibility and sucessional processes affecting seeding on pinyon-juniper types. In: Steve Monson (ed.), Ecology and management of pinyon-juniper communities in the interior west: abstracts. USDA Forest Serv., Rocky Mountain Research Station, Provo, Utah (in press).

Welsh, S. L., N. D. Atwood, S. Goodrich, and L. C. Higgins. 1993. A Utah flora. Second edition. Brigham Young Univ. print services. Provo, Ut. 